\title{
The Characteristics of the Typical Pattern of Jin-merchant Culture and Its Use in Traditional Decorative Design
}

\author{
XiangMing $\mathrm{Hu}^{1} \&$ XiaoMing Yang ${ }^{1}$ \\ ${ }^{1}$ College of Humanities, Donghua University, Songjiang, Shanghai, China \\ Correspondence: XiangMing Hu. College of humanities, Donghua University, Songjiang, Shanghai, 201620, \\ China. E-mail: nuczxbyjh@163.com
}

\author{
Received: May 7, 2020 \\ Accepted: May 18, 2020 \\ Online Published: May 31, 2020 \\ doi:10.5539/ass.v16n6p34 \\ URL: https://doi.org/10.5539/ass.v16n6p34
}

\begin{abstract}
Jin-merchant refers exclusively to the social group of merchants in ancient Chinese Shanxi province who ran businesses and engaged in commodity trading. During the Ming and Qing Dynasties, the Jin-merchants were the leading merchant groups with their wisdom and talent in merchandise management. In the long-term development, the Jin-merchant group gradually formed a relatively complete ideological and cultural system, supporting the development of the Jin-merchants cause. The Jin merchant culture, with Confucianism as its core, has been widely nourished by traditional Chinese culture and has internalized local traditional customs and folklore into their temperament and character, forming a series of specific historical and cultural symbols, which permeate the Jin-merchants code of living and life pursuit, and are gradually evolved into various decorative patterns to integrate into life, in which future generations can feel inspired and enlightened by traditional culture and Jin-merchant philosophy.
\end{abstract}

Keywords: traditional decoration design, typical pattern, Jin-merchant culture

During the Spring and Autumn period (722-476 BC), China was divided into many small states, State Jin which dominant area is mainly in Shanxi Province was the one of most important countries. Therefore, Shanxi is called Jin for short. Jin-merchant, commonly known as "Shanxi Merchant Group", also known as "Western Merchants", refers specifically to the social group of merchants who operated businesses and traded goods in ancient Chinese Shanxi province. The Jin merchants have always had a good reputation in business, and Shanxi province has been practicing a policy of opening up the country to commerce and agriculture since the time of the Jin state, which shows that Shanxi has had a tradition of promoting commerce and business since the ancient times. Shanxi businessmen walk the world, make abundant profits and form a deep commercial atmosphere.

The Ming Dynasty entered a period of unprecedented development of the commodity economy, with the germination and emergence of the domestic capitalist industry, the Jin-merchants, with their wisdom and talent in commodity management, constantly innovated business methods and forms of organization, and shone in the country's commercial activities, and gradually dominated among the various business groups. In the middle of the Ming Dynasty, the famous "ten merchant groups" of the country - Jin, Huizhou, Qilu, Jiangyou, Dongting, Ningbo, Long You, Min, Yue and Shaanxi among which Jin-merchant was the most wealthy and powerful merchant group, ranking at the top of the "ten merchant groups". The famous Qing Dynasty thinker Gong Zizhen once pointed out that "Shanxi is the richest province in China". In the early years of Xianfeng, in Jinzhong region of Shanxi Province, there were dozens of families who had more than a million of assets and the amount of which was estimated to be more than a hundred million taels, more than the inventory of the Qing government.

In addition, in China's recent pattern of passive opening up to the outside world, the Jin-merchants quickly found more room for development and formed a modern sense of the New Silk Road. It was once said that wherever there are sparrows, there are Shanxi merchants, and it can be seen that the number of Shanxi merchants and the scope of their activities are very large. By the Qing Dynasty, the Jin merchants also had the foresight to create the first Shanxi banking industry, so that China has since then specialized in the financial industry of the early banks, and once ruled the Qing Dynasty financial sector.

Jin-merchant, a group of merchants in Shanxi, formed by their own initiative, under the influence of historical and traditional culture, formed a unique business philosophy and an effective management system, when they 
almost dominated the financial capital and became the leading commercial capital of the country. At the same time, adhering to traditional Chinese Confucianism, Jin-merchant has inherited, integrated and accumulated rich traditional historical and cultural connotations, and formed the Jin-merchant cultural spirit.

First, the establishment of order is the political pursuit of Jin-merchant culture. Compared to other needs, the pursuit of social order and stability is more intense in Jin-merchant culture, which has a deep socio-historical and cultural background. Since the Spring and Autumn Period and the Warring States Period, the division and order of Chinese society has been solidified within a relatively stable framework, that is, the officials and gentries, peasants, industries and merchants have their place in the order and each has its own practice, which is the saying of the four types of people, and merchant is the end of the four types of people. This is a model of social power structure typical of feudal farming civilization. This sense of preservation of political status and social order is first and foremost reflected in the layout of the home. Because in the minds of the Jin-merchants, "the world is home and home is the world". The most representative are the Jin-merchants compounds scattered around Shanxi province, which are mostly balanced and symmetrical courtyards with a four-hall layout. The origin of the courtyard can be traced back to the Bronze Age, as it perfectly embodies the rituals of Confucianism and flourished throughout feudal society, becoming an orthodoxy and representative of traditional Chinese residential culture. For example, the Wang family, a great businessman compound in Ling Shi county gradually developed from west to east, from low to high, and built a huge complex of buildings, such as the "five streets, five forts and five ancestral halls", with a total area of more than 250,000 square meters, and the political aspirations of the Jin-merchants were cleverly embedded in the structural layout of the compound, such as the Qiao family, other a great businessman compound with the word "double happiness" in its layout and structure, the Wang family compound with the word "Wang" in its overall layout, the Taigu Sanduo Hall with the word "Shou" which It means longevity in its overall layout, and some compounds with the word "Ji" which It means auspicious ,or "Shi" which It means have a successful official career, in their layout; Shanshaan Hall in Liaocheng of Shandong Province has the overall structure of "mountain" type of one-piece buildings, etc. These typical Jin-merchant courtyards are rigorous and orderly, with a neutral axis and symmetry between the left and right, especially emphasizing a sense of unity and harmony, stability and order.

Second, honesty and trustworthiness is the pursuit of the value of Jin-merchant culture. The philosophical category of "sincerity" is proposed in the Confucian classic "Medievalism". "Faith" also occupies an important place in the spirit of Confucianism. Beginning with Mencius, faith became one of the human ethics. The Jin-merchants, while maintaining their integrity, reinforced this belief through "both internal and external training". The Jin-businessmen of financial power, credit is outstanding. During the Ming and Qing dynasties, Jin-merchants not only built many courtyards in Shanxi, but also high buildings in commercial centers and prosperous places throughout the country. Their luxury is the best proof of the strength of the Jin-merchants.

Third, the unity of righteousness and interest is the moral pursuit of Jin-merchant culture. In China's traditional farming civilization of thousands of years, commerce and merchants were not respected in ancient times, and since ancient times, there has been the maxim that "A gentleman is justice, a villain is profit", which is considered by most people as a guideline. However, this kind of secularism seems to be an alternative life choice of abandoning Confucianism and leaving the countryside, but Yan Yuan, a Ming Dynasty thinker and educator, has an extraordinary view. Yan Yuan's dialectical thinking broke through the confines of tradition and helped modern Chinese business to at least stand on its own feet, which is very commendable. Jin-merchant also used "the merchant and the scholar although different arts, they are concentric" to defend themselves, pointing out that "the good merchant benefits the system of righteousness, cultivate the wise line; the pursuit of merchants, although beneficial but not dirty", which is the empirical criticism of the "righteousness and profit, rational and desire opposing views". The Jin-merchants have incorporated the Confucian principle "to reach the goal is to help the world at the same time; to be poor is to do good for oneself" into the business spirit, winning the righteousness and benefiting oneself, gradually forming the business ethics of equal importance and unity of righteousness and profit. The most emblematic of this culture is the ridge-beast motif. The ridge-beast is a piece of animal that was placed on the roof of a large building in ancient times. They are categorized into running beasts, pendant beasts, "fairies" and owls, collectively known as "ridge-beasts". On the main ridge, a Kisser or looking beast is placed; on the drooping ridge, a drooping beast is placed; on the contrary ridge, a bumping beast is placed; and on the edge of the ridge, an walking beast is placed. There are up to ten beasts on the roofs of ancient buildings, including dragons, phoenixes, lions, sky horses, seahorses and other mythical animals. Ridge beast according to the direction of its mouth is divided into two categories, one is the mouth downward, was ridged, called chi dragon Kisser; and another category is the mouth upward, or open the mouth or shut up, called hanging beast. The open-mouthed ridge beast has the meaning of speaking for the people. The spine beasts in the 
courtyard of the Jin-merchant were mostly open-mouthed beasts, which reflected the moral duty of the Jin merchants to "always look north and south with their eaves erected, and to read the wind and frost with pride".

Fourth, harmony is the aesthetic pursuit of Jin-merchant culture. Live in harmony without demanding the same, the middle way of traditional Confucianism, is the principle of Jin-merchant culture in dealing with the world. Mediocrity is a reflection of the overall balance of the whole, unbiased and unparalleled; consistent, keeping the usual is called mediocrity. The Way of Mediocrity is a kind of neutral yardstick that seeks to live in harmony with all things, emphasizing not going to extremes, but taking the middle, where the two ends are both mutually supportive and complementary, to achieve a satisfactory state of affairs. The Jinshang culture holds the idea of middle-ground as the highest moral standard, and as the basic principle and method of dealing with things. Chinese traditional culture is dominated by the "Confucian culture", which is essentially an open system. The Jin-merchant culture embodies different elements of thinking such as Confucianism, Buddhism and Taoism in the pattern composition. Take the Qiao family courtyard as an example, there are wooden carvings in various parts of the courtyard, such as the celestial officials giving blessings, the rising moon, the auspicious auspiciousness from Kirin, the three stars of prosperity and longevity, and the two immortals He-He. The fence carving in the corridor in front of some courtyards, from east to west, shows a magpie in a plum, a kui-dragon in the air, a hundred grapes, a heron playing a lotus, and a sparrow playing a chrysanthemum. The entrance to the eastern courtyard is carved with four seasons of flowers, four fruits, and Chinese calligraphy and painting, which is also meant to be auspicious. The stone carvings include "Golden Lion and White Elephant", " Monkey on horse, that means be a king at once", "Become officials from generation to generation", "Fishermen, Woodcutters Scholar and Farmers" and "Muggles offer gifts for longevity" etc.

Decorative motifs are considered "solid history" and are closely related to the natural environment and human context of the era. The typical patterns of Jin-merchant culture reflect the political pursuits, value pursuits, moral pursuits and aesthetic pursuits of the Jin-merchant community, and these profound cultural connotations are reflected in the decorative designs of different periods of Jin-merchant life, which illustrate the sound of an era and leave an endless charm.

\section{References}

Bangu. (1962). Hanshu - Geography (Vol. XXVIII, p. 1648). Beijing: China Books.

Fan, Y. (1965). The Later Han Book - County State I, Zhixix. Beijing: China Books.

Fan, Z. Y. (2002). The Complete Works of Fan Wenzhenggong (p. 29). Chengdu: Sichuan University Press.

Gao, Y. Y. (2007). Cultural Traditions, Institutional Performance and Path Dependence of Jin Merchants in the Ming and Qing dynasties (p. 35). Liaoning University.

Han Book - Food and Goods (4th Shang). (2002). Urumqi: Xinjiang People's Publishing House.

Li, X. F. (2006). The Moral Construction of the Righteousness and Credibility - On the Cultural Spirit of the Jinshang. Guangming Daily.

Liang, Q. C. (1936). An Anthology of the Drinking Ice Room. Beijing: China Books.

Sima, Q. (1982). Historic Records - A Chronicle of the Goods Culture (Vol. 129, p. 3259). Beijing: China Books.

Sun, L. P. (2001). Shanxi Courtyard Culture Pick Up. A Study of the History of the Jin Merchants. Taiyuan: Shanxi People's Publishing House.

Zhang, S. (2016). The Soul of Jinshang and the Spirit of Jinshang. Shanxi Daily, 2016-02-23(C02).

Zhao, D. R. (2001). The Jin Merchants from a Broad Historical Perspective. Shanxi People's Publishing House, Research on the History of Jinshang.

\section{Copyrights}

Copyright for this article is retained by the author(s), with first publication rights granted to the journal.

This is an open-access article distributed under the terms and conditions of the Creative Commons Attribution license (http://creativecommons.org/licenses/by/4.0/). 